\title{
The Re-Emergence of Critical Pedagogy: A Three-Dimensional Framework for Teacher Education in the Age of Teacher Effectiveness
}

\author{
Nicholas J. Shudak \\ University of South Dakota, Vermillion, USA \\ Email: nicholas.shudak@usd.edu, nshudak@gmail.com
}

Received 22 April 2014; revised 20 May 2014; accepted 10 June 2014

Copyright (C) 2014 by author and Scientific Research Publishing Inc.

This work is licensed under the Creative Commons Attribution International License (CC BY). http://creativecommons.org/licenses/by/4.0/

(c) (i) Open Access

\begin{abstract}
In light of the extensive treatment given over its thirty year existence, this article develops a framework for helping teachers understand the applicability and relevance of critical pedagogy in the classroom during this age of effectiveness and standardization. To do this, critical pedagogy is theoretically framed three-dimensionally. The purpose is to help teachers think through critical pedagogy in a way that might encourage them to analyze their own practices and thus create and enact critical pedagogies that are uniquely their own. The first dimension pertains to its contested terrain. An understanding of critical pedagogy must begin with a disclaimer. This disclaimer suggests that though there are common objectives, there are key points of contestation. The second dimension, then, seeks to find the common ground. This dimension focuses on the commitments of critical pedagogy, and thus, the commitments of those who might try. Lastly, critical pedagogy impels teachers to use their classrooms to make life more humane. To aid in this task, teachers engaging in critical pedagogics take certain philosophical positions, the third dimension of critical pedagogy.
\end{abstract}

\section{Keywords}

Teacher Education, Critical Pedagogy, Standardization, Teacher Effectiveness, Philosophy of Education, Democratic Education, Educational Theory, Paulo Freire, Philosophy for Children, p4c, Being, Becoming, Ontology, Epistemology, Ethics, Trust, Politics, Literacy 


\section{Introduction}

At the outset of his Introduction to Thinking in Education, Matthew Lipman comments that "if there is any institution that can legitimately claim to be worldwide, it is probably the school” (Lipman, 1991: p. 1). And on Lipman's terms, the one presupposition that perhaps all people can agree on regarding why children go to school is that they go to school to learn. However, while scratching the surface only slightly deeper, we come across questions such as "Why should children go to school to learn?" Or, "What should children be learning when they in fact learn in school?" From these questions, what quickly becomes evident is that the ground for agreement regarding what Cremin (1965) referred to as the "whys and wherefores" of schooling is quite unstable, and because so, contestable.

Answers to such vexing yet important questions have long been a theoretical focus for scholars in the varied discursive realms of education, philosophy, sociology, psychology, political science, anthropology and the many combined variants thereof. Recent arguments have been put forth by Larson (2014), suggesting new ontological and epistemological positions from which schooling in the US and elsewhere around the world can "start over." Larson's point as an educational researcher is seemingly simple. Borrowing a key term from Tyack and Cuban (1995), there has been too much "tinkering” with the US educational system. As she sees it, the tinkering has had very little sustainable results regarding outcomes toward fairness and equity within a democratic society, and has been too narrowly construed along the lines of achievement through standardization (Larson, 2014: p. 14). To this extent, Larson borrows from Bruns (2008) in which schools are experiencing a "casual collapse,” a collapse toward purposelessness and irrelevancy in rapidly changing societies. Simply put, "Enough is enough."

It is easy to agree with the overall theses put forth by Larson and many historical others. What seems elusive, however, is the creation of sustainable theoretical discourses tempered by classroom practice and reflection; discourses designed to help teachers think through the existential realities and tensions and contradictions within their classrooms; discourses keen on helping teachers work toward changing those realities, and making classrooms places where learning is facilitated, meaning is made, and knowledge is produced as Larson would have us.

During the late $20^{\text {th }}$ century, the educational world saw the emergence of just such a discourse, one that still possesses potential and insights for classroom teachers. The discourse in mind is the grassroots-powerful discourse of critical pedagogy. Critical pedagogy emerged as an amalgamation of many areas of academic inquiry, but in particular, sociology and critical theory (McLaren, 1998b).

From its emergence and throughout its development, critical pedagogy has been positioned as a broad and encapsulating theory of education. Over the course of its development, critical pedagogy has experienced a litany of introduction (Kincheloe, 2005; McLaren, 1998b; Wink, 2005), support (Giroux, 2001; Giroux \& McLaren, 1986; Shor \& Freire, 1988), suggestion (Biesta, 1998; Gur-Ze’ev, 1998; Liston \& Zeichner, 1987; McLaren, 1998a; Weiler, 1988), and criticism (Ellsworth, 1989; Knight \& Pearl, 2000; Lather, 1998, 2001), lending credence to Wink’s (2005) observation that critical pedagogy is in a continuous process of evolution and development.

In light of the extensive treatment given over its thirty year existence, this article develops a framework for helping teachers understand the applicability and relevance of critical pedagogy in the classroom during this age of effectiveness and standardization. To do this, critical pedagogy is theoretically framed three-dimensionally. The purpose is to help teachers think through critical pedagogy in a way that might encourage them to analyze their own practices and thus create and enact critical pedagogies that are uniquely their own. In this sense, critical pedagogy becomes less of a theory of education and more of a way of being. It becomes similar to Dewey's (1944) understanding of democracy as a way of life or mode of associational living.

The first dimension pertains to its contested terrain. An understanding of critical pedagogy must begin with a disclaimer. This disclaimer suggests that though there are common objectives, there are key points of contestation. The second dimension, then, seeks to find the common ground. This dimension focuses on the commitments of critical pedagogy, and thus, the commitments of those who might try. Lastly, critical pedagogy impels teachers to use their classrooms to make life more humane. To aid in this task, teachers engaging in critical pedagogics take certain philosophical positions, the third dimension of critical pedagogy. And as a conclusion, this article ends with a brief discussion regarding the dangers of reducing critical pedagogy to mere methodology.

\section{A Definition of Terms}

Before developing the three-dimensional frame, and as a way to address Liston and Zeichner's (1987) call that 
what critical pedagogy needs is clear debate as to what constitutes a critical pedagogy, this article's first step is to address the terms of "critical" and "pedagogy."

Pedagogy is a term still unfamiliar to many inservice and preservice teachers. Generically speaking, it can mean the confluence of the art and science of teaching. But this is kind of a barren dictionary sense of the term. This article, and the texts from which it borrows, considers pedagogy in terms of classroom action consciously animating from philosophical and socio-political positions. In this regard, the action accords with a wider vision and purpose for what goes on in classrooms and schools. Pedagogy, then, is quite directional. According to this conceptualization, pedagogy is much more than the art of teaching and is greater than mere methodology. It encompasses both but is not defined by either.

Wink (2005) considers pedagogy as that which happens when teaching and learning reciprocally interact and influence each other. For her, pedagogy "is about the visible and hidden human interactions between a teacher and a learner, whether they are in a classroom or in the larger community" (1). McLaren (1998a), in quoting Roger Simon, infuses politics. Simon suggests that pedagogy "is simultaneously talk about the details of what students and others might do together and the cultural politics such practices support" (165). Pedagogy as it pertains to classroom situations is conscious human interaction oriented toward learning something with purpose. Pedagogy is something powerful that has immediate relevance and meaning to students' lives. In this regard it is something deeper and philosophically more powerful than teaching. Pedagogy as described above is an understanding of the term as usually qualified by "critical."

Critical, then, as it qualifies pedagogy is less about necessity, criticism, judgment, or evaluation. Critical is, however, suggestive of the analytical nature of the pedagogy. Borrowing again from Wink, pedagogy that is critical is a searching pedagogy. It seeks to look beyond the surface to interrogate human authorship and authority. It looks within and without the given subject-matter for answers and understanding to issues impacting students' lives. A pedagogy that is critical leaves no stone unturned in its search for truths, understanding and meaning, and is also quite cognizant of why it is overturning stones in the first place.

\section{The Contested Terrain of Critical Pedagogy: The First Dimension}

If one were to view critical pedagogy in part as an educational philosophy concerned with directional change and transformation, it would seem that it too must be dynamic. What makes critical pedagogy so maddening is that a condition of studying, theorizing, and enacting critical pedagogy is dealing with the ambivalences between available examples.

McLaren's (1998a) and Gur-Ze'ev's (1998) observations on this point prove instructive. They suggest that there are important differences found between various theoretical and enacted critical pedagogies such that there is no such thing as the one critical pedagogy. Rather, there are several critical pedagogies that are at times gripped with tensions between them, though united in terms of guiding objectives toward an overall project. McLaren's and Gur-Ze'ev's observations suggest that teachers enact $a$ critical pedagogy that is uniquely theirs, tailored to and by the needs of their situations - a way of being.

Critical pedagogy, in sounding theoretically robust and rarified, is problematic to many. To the uninitiated, the written discursive formations - the language used — convey almost nothing. The theory undergirding critical pedagogy is at times tough to wade through. Many teacher education students simply want to learn observable and replicable strategies for positively influencing student outcomes, not to wade through theory. On this note, critics Knight and Pearl (2000) are quick to point out that for a discourse so concerned with literacy, language, and communication, one that has unleashed an "unrelenting assault on the oppressiveness of schooling," the lofty wordplay of critical pedagogy suggests guilt of "diversion, division, illusion, and confusion” (p. 197).

A response to this concern is that the new language of critical pedagogy is what helps people break free from oppressive and debilitating forms of thought and action. Not only are effective teaching strategies necessary, but so is an understanding of the theoretical and political positions that make one outcome more worthy of others. With that said, countenancing what Connolly refers to as "essentially contested concepts" (Connolly, 1983) such as "hegemony" is not the problem. The problem is the lack of time and opportunity with examples to help students conceptualize the power of new language. Unfortunately, this is largely a problem with the design of teacher education more so than with the discourse. However, and arguably with the exception of Wink's work (2005), rarely have critical pedagogy discourses used theoretically-laden concepts such as hegemony on microcosmic scales that might help teachers analyze student relations on the playground, in the hallways, or during 
in-class work at the K-12 levels. The concepts behind the language of critical pedagogy are without a doubt applicable to the lives of those in schools as the work of Wink (2005) and McLaren (1998a) make evident, though quite differently and for different audiences.

Critical pedagogy is equally problematic for those familiar with it. Critical pedagogy in this sense mirrors Debord's spectacle. For some it is basically a discourse that "discourses endlessly upon itself in an uninterrupted monologue of self-praise” and aggrandizement (Debord, 2002: p. 19). "In many ways,” according to Knight and Pearl, critical pedagogy is the "mirror image of... [politically motivated take-overs] of schooling. Both are remote from classroom reality, and neither knows what it is talking about” (Knight \& Pearl, 2000: p. 198).

Knight and Pearl's sentiment echoes the critique that arguably started the windfall of problematizing: Ellsworth's Why Doesn't This Feel Empowering? Working Through the Repressive Myths of Critical Pedagogy (Ellsworth, 1989). Ellsworth, amongst other things, is concerned with the high levels of abstraction found in the discourse. The academized abstraction seems removed from the tangible daily realities of the classroom, the purpose for school, and the roles of students in their political and historical contexts. For Ellsworth, the abstractness of critical pedagogy mires it in platitude, far removed from applicability. The flashy catch phrases are basically meaningless on face value.

Ellsworth's problematizing challenges the truth claims of critical pedagogy as a theory of education designed to alter oppressive power relations. Ellsworth's challenge is that "while the literature states implicitly or explicitly that critical pedagogy is political, there have been no sustained research attempts to explore whether or how the practices it prescribes actually alter specific power relations outside or inside schools” (p. 301). And several years later, the literature is still a bit anemic on this point.

Ayers, Michie and Rome (2004) suggest a corrective. In an article chronicling their attempts at practicing and implementing critical pedagogy and its effects on teacher candidates, they put forth a rethinking of the terms. Regarding critical pedagogy, they comment that "Whatever insurgent energy [that] once pulsed through those words—giving them life and investing them with power and possibility—has been largely lost, their meaning sapped away with overuse and misuse, reduction and dogmatic application” (p. 123).

Their suggestion to the above problematics and ambiguity is to consider critical pedagogy on a less grandiose scale. They would have teachers interested in change and agency think of critical pedagogy metaphorically and in terms of "Embers of Hope." The metaphor is such that the embers are efficacious enough to start the fire of change, but they are not sustenance enough to be the fire. Critical pedagogy, then, should not be viewed as a metanarrative-like theory of education and schooling. Critical pedagogies, then, are the embers that help teachers build fires.

\section{Commitments of Critical Pedagogy: The Second Dimension}

In light of the above, what is becoming evident is how critical pedagogy is more of a way of being than a theory of education. However, for something to be a way of being, to guide or influence thought and action in the classroom, there must be commitments to which a person adheres. This section discusses two main commitments of critical pedagogy: a commitment to a political way of being in the classroom, and, a commitment to the power of literacy in shaping lives.

\subsection{A Political Commitment}

Critical pedagogy is political. Political in this sense is a reference to forms of social organization and arrangements, on any scale, that are responsible for the distribution of goods and services/resources: power. In this regard, a school is a political entity in that it has a unique form or organization within its walls that distributes goods (grades, pencils, Kleenex, books, notebooks, art smocks, book covers, time for specials, etc.) as well as services/resources (teachers, counselors, social workers, paraprofessionals, specialists, etc.). Classrooms, then, are also political because they embody forms of social organization and arrangements that are quite distributive, and that oftentimes mirror the arrangements of the encapsulating school.

Teachers who view themselves as critical pedagogues are quite conscious of how schools and classrooms are political in the above regards. They understand that their very existence, the existence of the students, and the materials in the classroom are the result of a number of political decisions and embedded practices. A starting off point for this discussion is again with McLaren (1998a) who asserts that "the struggle over education is fundamentally linked to struggles in the larger theater of social and political life” (p. 460). Followed, then, by Kincheloe’s 
claim that the proponents of critical pedagogy "understand that every dimension of schooling and every form of educational practice are politically contested spaces” (Kincheloe, 2005: p. 2).

To teachers unfamiliar with this way of thinking about schools and schooling, this might sound daunting. However, it is quite commonsensical and is what many teachers do as a best practice. In other words, practicing critical pedagogics, simply stated, is a commitment teachers make to bring a political and social consciousness to the classroom in democratic societies, especially an awareness of how people relate to each other, and how power is implicated in relationships.

Studying how humans relate to other humans and their environments in scientific and comedic or tragic senses is the backbone of a liberal arts education. If, according to Freire (1998a), "the fundamental condition of life is the condition of relationship, relationship to oneself and to the surrounding world" (75), then critical pedagogy would have teachers elucidate how the organization of their classrooms influence relationships in just and equitable ways conducive for democratic living.

Critical pedagogy, then, is a commitment to a way of life that is political. It is a commitment to "challenge our own orthodoxy [of practices and relationships], to rethink basic principles, to storm our own headquarters... [and] to act on behalf of our students, ourselves, and our deepest hopes for a better world” (Ayers, Michie, \& Rome, 2004: p. 123).

There is a powerful default position that goes along with this commitment. The default position is the belief that, and generally speaking, many societies are organized in ways that create conditions impelling people to relate to each other in antidemocratic, hierarchical and oppressive ways. Schools, then, mirror and even reproduce such conditions. On this point, McLaren and many others within the critical pedagogy discourses, argue that though "Americans have assumed that schools function as a mechanism for the development of a democratic and egalitarian social order... [one that follows in] the broad Western humanist tradition for self and social empowerment” (McLaren, 1998b: p. 166), schools are actually sites wherein an oppressive and unequal social order is reproduced.

One of the best and earliest empirical studies trying to prove this point of reproduction is Anyon's ethnography, "Social Class and the Hidden Curriculum of Work" (Anyon, [1980] 1983). This was a pre-critical pedagogy study that has influentially informed the discourse. In this relatively small study, Anyon analyzes how classroom structures such as work-product, materials, forms of evaluation, control, and instructional methodology of five fifth grade classrooms differently prepare students to relate to the "system of ownership of symbolic and physical capital, to authority and control, and to their own productive activity...” (p. 163).

Anyon's study inventories how a teacher's mode of being and way of life in the classroom has direct, and sometimes dire, consequences for their students' ability to obtain equal occupational opportunity after schooling. For example, the study indicates that students from working class backgrounds are more than likely to experience classroom environments approximating the types of relationships to ownership experienced in the bluecollar world. Anyon states that "Their present schoolwork is appropriate preparation for future wage labor that is mechanical and routine" and that prepares them to work as a source of profit to others (ibid.). The attitudes in relation to authority, in particular resistance, form quite early according to Anyon.

And for students on the other end of the spectrum? Those attending schools she calls the "executive elite" experience classroom environments preparing them for leadership positions. At such schools, students learn "knowledge of and practice in manipulating the socially legitimated tools of analysis...[that] are necessary for [the] control of a production system" and for controlling labor (p. 165). Anyon's study is but one that indicates how schooling and embedded teaching practices have political, social, and economic implications. Her overall project is an attempt to show that schools in the United States are not egalitarian in the wider political scope of things as many would hope.

There is a silver lining, though, to the above position. Because critical pedagogy in the theoretical sense views schools in terms of transformation and hope and possibility, there is a complementary default position. This position is the belief that schools actually exist as sites in which the conditions of humans and the human condition can be greatly improved. It is a commitment to Dewey's position that through the school, "we shall have the deepest and best guaranty of a larger society which is worthy, lovely, and harmonious” (Dewey, 1990: p. 29).

In an applicable sense, critical pedagogy would have teachers, perhaps as their first and foremost act, struggle over the very meaning and purpose of schooling. Meaning and purpose are what guide and determine the forms of organization in the classroom, are what guide and determine knowledge producing practices. Struggling over purpose is basically a struggle over the connection between schooling with the encapsulating spheres of society 
and how they function together, and, toward what ends do they function. This step, for many, is the first step toward mitigating asymmetrical power relations in their rooms that might in fact be responsible for oppressive classroom conditions.

Schools and classrooms—-schooling —is anything but neutral. If one assumes that his/her pedagogy is void of politics, critical pedagogy challenges that position as a politically-laden position. The position of neutrality is ideological and the discourses of critical pedagogy provide individuals with tools and language for such an analysis (see Ellsworth, 1989; Freire, 2002; Kincheloe, 2005; Lather, 1998; McLaren, 1998a, 1998b; Wink, 2005).

\subsection{A Commitment to the Power of Literacy}

The second commitment pertains to literacy. This commitment is ostensibly what makes critical pedagogy relevant across all subjects and grade levels. Wink (2005) comments that critical pedagogy begins and ends with literacy (10). Any description of critical pedagogy, theoretical or otherwise, must invariably revolve around the importance of literacy in empowering people to identify and change oppressive conditions. Literacy, in a critical pedagogy sense, is not a skill that helps people assimilate to conditions of oppression and oppressive relations. Literacy is empowering and transformative.

This type of literacy, according to Freire and Macedo (1987), is a literacy that teaches students how to read the world and the word. Theirs is a playful use of words that makes quite a bit of sense. On their terms, "Reading the world always precedes reading the word, and reading the word implies continually reading the world" (35). In other words, how a student reads and comprehends the written words in a text and what that student does with it entirely depends on how that student reads (looks at, comprehends, understands) her world. Reading the world is cultural, historical, and political, thus, the subsequent reading of the word is as well.

For teachers, this is a significant shift in understanding literacy. Both forms of reading are functions of comprehension that constantly interact. For some students, the reading of the world and word are harmonious exercises, reaffirming one's existence; whereas for others the two readings are disjointed. It is important to keep in mind that neither one-a reading of the world or the word — without the other is sufficient enough for any program to be called a literacy program from a critical pedagogy perspective.

The foundation for a critical pedagogy inspired literacy instruction comes from the work of educational theorist Paulo Freire. Though Freire was generally concerned with preliterate adult populations in Brazil, his ideas involving generative words and codifications are quite salient in school settings. Borrowing from Fiore and Elsasser (1987), the goal of this type of literacy is "to help students become critically conscious of the connection between their own lives and the larger society and to empower them to use literacy as a means of changing their own environment” (p. 89).

Thinking of literacy generatively, or in terms of generativity, simply makes sense. The cognitive psychologists might refer to this as scaffolding, but with a political twist. Generative words and themes, then, are not abstractions from students' lives and understandings of reality. Rather, they are integrally a part of their lives, the problems they face, and the questions they have.

Generative words help students name the world, an ever important aspect for pedagogy to be critical. For Freire (2002), "To exist, humanly, is to name the world, to change it" (p. 88). A literacy program is much more than labeling things in a classroom with words or merely memorizing bold print words appearing throughout the chapters. Literacy is a constant activity challenging students to think about their lives, the world around them, and how they fit into the mix, and of course using texts to help. Generative words, then, help students generate more words, thoughts, emotions, forms of action.

One way of working with generative words and themes, something that works almost regardless of age or grade level, is to use what Freirean's call "codifications." Codifications are generative.

Codifications are representations of powerful concepts affecting students' lives. They are captured in picture form whether on paper, in the dirt, on a wall, in a photograph, a collage, etc. Codifications, then, are pictorial codes about aspects of life with political implications. According to Wallerstein (1983), "No matter what the form, code is a projective device that is emotionally laden and identifiable to students...In essence, a code sums up or 'codifies' into one statement a problem (or contradiction) that people recognize in their lives...” (quoted in Wink, 2005: p. 38). Wink also offers an understanding of codification submitted by Freeman and Freeman (1992). Theirs suggests that a code is a "whole story, picture, or file...based on the learners' lives. Learners identify 
and solve real-life problems... [and] work cooperatively to solve problems...” (p. 112) through the use of such codes. In the sense of using whole stories through picture books, the works of those in the philosophy for children (p4c) movement have something to offer critical pedagogy and its commitment to literacy (Goering, Shudak, \& Wartenberg, 2013).

Sticking with the notion of codifications within literacy, the examples are many and varied. For early elementary students, codifications might include pictures of students on a playground in situations approximating bullying and the possible responses to such situations. A codification could also be the assembling of a decoupage project with integrated writing and storytelling about the included pictures. A picture of a school juxtaposed to a church with similar architecture is a codification. Another codification might include the physical representation of people within various forms of media. The point of the codifications is to encourage students to read the world, to apply words to it, then to read their words as a way to generate more words, thoughts, actions. This is a $\mathrm{K}-12$ exercise in literacy.

Teachers who would consider themselves critical pedagogues make two related commitments: one to politics and the other to literacy. For such teachers, there is an understanding that their practices in the classrooms have political implications and they are conscious of those implications and why they engage in such practices. Also, such teachers are committed to literacy. For teachers engaging in critical pedagogics, regardless of level, literacy is much more than decoding and fluency. Literacy is the process of creating words that come from students' worlds in order to build understandings into their particular contexts and to communicate with others about them.

\section{Philosophical Positions: The Third Dimension}

The third dimension of critical pedagogy borrows from three areas of philosophical inquiry-ontology, epistemology, ethics - to help inform one's way of being in the classroom. Ontology is the philosophical area of inquiry concerned with asking what it means "to be" or to exist as human beings. Epistemology is concerned with asking where knowledge comes from. And ethics is concerned with the rightness or wrongness of conduct. This dimension, and the following discussion, borrows largely from the works of Paulo Freire, whose work is foundational to understanding critical pedagogy.

\subsection{Ontology}

Regarding ontology, Freire is quite clear. According to Freire, there are two ontological possibilities for human beings. We can view ourselves and our students as completed beings or uncompleted beings in the process of becoming. It is a choice between ontologies of being versus becoming.

Again, here is an example of the wordplay that makes this discourse maddening to some. However, there is something quite instructive here. The ontology of being is a way of looking at human beings as finished products with no hope of change or transformation. A poor or unruly student is simply poor and unruly and always will be. The teacher can do nothing to change this.

The ontology of becoming, on the other hand, views people as being in a constant process of becoming whatever it is that they want to become. There is great power in Freire's ontology of becoming. It is infused with hope for change, transformation, betterment. If a student is poor or unruly, this is not a fixed condition. It is the teacher's responsibility to work with the student toward change. Regarding the process of becoming, Freire states "I like to be human because in my unfinishedness I know that I am conditioned. Yet conscious of such conditioning, I know that I can go beyond it, which is the essential difference between conditioned and determined existence” (Freire, 1998b: p. 54). On Freire’s terms, it is the essential difference between an ontology of becoming versus an ontology of being.

Freire's framework of incompletion helps teachers become conscious of the conditioning teachers and students bring to the classroom. It as a moving away from, or the transformation if you will, of a consciousness that accepts what is in life as what is destined to be in one's life. This is perhaps our charge as teachers: to help students realize that life is not destined or predetermined; that students can act to intervene in their own lives, creating possibilities for themselves. The ontological consideration, then, of critical pedagogy is that of incompletion (or becoming). It is a consideration that challenges the note cards codifying students' strengths and weaknesses that get passed from one grade level to the next and from one teacher to the next. 


\subsection{Epistemology}

For pedagogy to be critical, an epistemological position viewing dialogue as a legitimate way of knowing is essential. It is important to note that dialogue is more than mere conversation and discussion of a topic. Dialogue is also more than a "romantic pedagogical mode that 'exoticizes' discussing lived experiences as a process of coming to voice" (Macedo, 2002: p. 18). Dialogue is more than group-therapy and is antithetical to the conversational space wherein people rhapsodize narcissistically with sentimentally similar others. Dialogue is a way of knowing with and through others. This is the kind of knowing in schools that critical pedagogy is concerned with.

Dialogue is epistemological when it is in relationship with objects of knowledge. This is what Freire refers to as an epistemological relationship. An object of knowledge, or a cognizable object, in school settings is any particular topic of study, the more specific the better. Dialogue, then, is the process of knowing and learning that allows students to use experiences in and with the world, in concert with studying an object of knowledge, to learn more about self, others, the world, and the object itself. This is the form of learning and knowing that is, for the most part, absent in schools.

A brief example to look at through a critically pedagogical lens, and at the elementary level, is to view Columbus Day as the cognizable object. With a commitment to political directionality and literacy, the teacher in this case would like to problematize Columbus Day by having students read Jane Yolen's Encounter (1996), which acts as a counter-narrative to the dominant mythology of Columbus as hero. The text is a source helping students read a different world, a removed world, and challenges them to re-read their own world. Dialogue, then, as a process of knowing in the classroom challenges the students to reconcile their own experiences with Columbus Day with the experiences they read about from the text. Some questions the teacher might ask are: "How might the celebration of this individual be differently perceived?" Or, "Is Columbus Day a day worth celebrating, why or why not?" And perhaps even, "What should we do about how we feel?” Such teaching encourages students to think about the politics of culture, and about cultural assumptions and taken-for-granteds.

The efficacy of dialogue as a process of knowing relies on the epistemological curiosity of the students. There is no way of guaranteeing that an object of knowledge is going to be something toward which all students are epistemologically curious. A good place to start is with objects that are affecting the students' lives, or objects with which students are convivial.

The pedagogical act of dialoguing with other people about an object of knowledge is an act of reflection and intervention. It is an act of reflection in that in order for dialogue to take place, students engage in thought regarding the object of knowledge, their experiences with it, and develop questions or concerns before commenting to others. It is also an act of intervention because any engagement with others is, by default, an intervening into the subjectivity of others. The hope is that students' subjectivity is informed by learning about the object in question. Such acts allow students to participate in the historical processes that shape people's lives. Learning is not always, nor should it be, affirming.

Dialogue, according to Freire, is an "existential necessity" and aligns nicely with his ontology of becoming. Dialogue humanizes people. It is a process of creation wherein people realize that we are uncompleted beings; it helps make us conscious of our incompletion, and that we can overcome our conditions that, well, condition us. This empowering realization suggests that our current existential situations are not fate or destiny; that because we are incomplete, we, as human beings, possess the power to direct our energy toward becoming whatever it is we want to become, assuming we want to become something good and positive in the world.

\subsection{Ethics}

Simply stated, "ethics is the study of moral values," the effect those values have on human conduct, and how to understand, clarify, prioritize, and practice values (Weston, 2011: p. 6). For critical pedagogy, a moral value that is at least prioritized and practiced, if not always well understood and clarified, is that of trust. As mentioned above, dialogue as epistemology, as a way of knowing, requires certain classroom conditions. For dialogue to occur, the students and teacher are in relation to one another in a way not usually found in traditionally organized classrooms. A necessary condition for classrooms amenable to dialogical ways of knowing is safety. For honest dialogue and struggle to occur students must feel safe in doing so. Such classrooms operate as a result of prioritizing the moral value of trust. Trust here is considered a moral value simply because trust affects how people act in relation to each other. 
The epistemology of dialogue and the ethics of trust are quite intertwined. It almost goes without saying that for dialogue to occur people must trust in each other. Dialogue through the ethic of trust is void of the oppressive and dehumanizing characteristics of manipulation, of over-generalizing truth claims for one's benefit, and of relying on slogan and cliché as a substitute for thought. It is also void of relations of domination. The relationship between those in the classroom operates not on the usual vertical relational hierarchy wherein the teacher is the dominant and the students are subordinate. The classroom rather operates according to a horizontal relational frame where all are teachers and all are learners during the dialogical process.

Freire speaks to the interrelatedness of dialogue as epistemology and trust as the ethic involved. "Dialogue," he submits, "requires an intense faith in humankind, faith in their power to make and remake, to create and recreate, faith in their vocation to be more fully human (which is not the privilege of an elite, but the birthright of all)" (Freire, 2002: pp. 90-91). What Freire refers to as faith "is an a priori requirement for dialogue; the 'dialogical man' believes in others even before he meets them face to face. His faith, however, is not naïve” (ibid.).

The ethic of trust-having faith in the goodness of others in the classroom-is paramount for epistemologically-laden dialogue to take place. But as Freire stated, the trust is not a naïve trust. As the ontology of incompletion suggests, people are imperfect on our way toward becoming humanized. Thus it is imperative that the critically pedagogical teacher be critical, reflective, and analytical regarding the conduct of the class and its tenor. If trust is challenged, there is a reason which the teacher should seek to uncover. Once the reason is found, steps toward the re-birth and re-establishment of trust should immediately begin. If trust is challenged, it is not a reason to give up, but a reason to persist, a reason to continue, and the students should be involved in keeping the faith that a classroom predicated on dialogue through trust should persist. "Without this faith in people," asserts Freire, "dialogue is a farce which inevitably degenerates into paternalistic manipulation” (Freire, 2002: p. 91).

Trust, as has been shown above, is an indispensable feature of a critically pedagogical classroom. As the students join the ranks of the teachers through dialogue, they consciously engage in their own process of becoming - which again is the struggle to exist as a conditioned and not determined actor in and with the world. No longer are things being done "to" them in school, but students are doing things "with" each other through dialogue and trust.

\section{Conclusion}

If the above are the "what" of critical pedagogy, then what is the "how?" The "how" of anything in the classroom is the practitioner's dilemma. Many teachers are constantly looking for the one best way in which to teach a particular subject, just as states and districts are still after the elusive "one best system" (Tyack, 1974) as evidenced by the Common Core era in the United States.

This search is an understandable proclivity of teachers. After all, much of what teacher education students experience in their programming is an inordinate focus on procedural step-by-step methods rather than focusing on conceptual understandings that lead to multiple and even competing forms of methodologies. Searching for the one best way unfortunately reduces critical pedagogy to prescriptive methodology. The difficulty of writing about critical pedagogy in terms of methodological practice is that any attempt is really the writing of what cannot be or should not be written (Wink, 2005). Again, it is a way of being in the classroom and not a method of teaching.

In looking at critical pedagogy as a way of being, Person A cannot tell Person B what to do regarding practice. Such an act is prescriptive and substitutive of critical reflection and intervention. Person B can seek counsel, but in the end, Person B must act on her own. The counsel Person B seeks can be in the form of narratives of others who might have been in similar situations (Shor, 1987; Wink, 2005), after all, this is something teachers do regularly. However, critical pedagogy requires the teacher "to name, to reflect critically, [and] to act" (Wink paraphrasing Freire, 2005). Wink considers this to be the best definition of critical pedagogy, and it is probably the closest illustration as to how critical pedagogy looks as a way of being. Critical pedagogy eschews prescriptive methodology and instead requires teachers to get used to naming, reflecting, and acting in accordance with the commitments developed above.

Critical pedagogy is definitely not without its difficulties. One such difficulty, evidenced by the above discussion, is that there are many and at times competing discourses as to what is critical pedagogy. This article was an attempt to map such a terrain three dimensionally, as a way to frame critical pedagogy as a mode of being in the 
classroom rather than an encompassing theory of education.

For those who would try, critical pedagogy involves a commitment to politics and literacy, and, is predicated on philosophical positions pertaining to knowing, being, and conduct in the classroom. The commitments are to a directional politics of social equity and relational equality, and, to literacy programming that helps students read and re-read their encapsulating world and the textual word.

Critical pedagogy is also informed by three philosophical positions. The ontological position considers people to exist in a conditioned state of incompletion, that we view ourselves and others as existing in the process of becoming. The epistemological position considers knowledge to come from dialogue between those in the classroom as they are in relation to each other, the world, and with an object of knowledge. The final position is an ethical one. This position considers trust as a foundational moral value.

Critical pedagogy as a way of being is something that is lived and is not easy. In terms of practicing critical pedagogy, it might help to think of critical pedagogy as the nexus between the above dimensions and what one's existential reality demands.

\section{References}

Anyon, J. (1983). Social Class and the Hidden Curriculum of Work. In H. Giroux and D. Purpel (Eds.), The Hidden Curriculum and Moral Education: Deception or Discovery? (pp. 143-167). Berkeley, CA: McCutchan Publishing.

Ayers, W., Michie, G., \& Rome, A. (2004). Embers of Hope: In Search of a Meaningful Critical Pedagogy. Teacher Education Quarterly, 31, 123-130.

Biesta, G. J. J. (1998). Say You Want a Revolution...Suggestions for the Impossible Future of Critical Pedagogy. Educational Theory, 48, 499-510. http://dx.doi.org/10.1111/j.1741-5446.1998.00499.x

Bruns, A. (2008). Blogs, Wikipedia, Second Life, and Beyond: From Production to Produsage. New York: Lang.

Connolly, W. E. (1983). The Terms of Political Discourse (2nd ed.). Princeton, NJ: Princeton University Press.

Cremin, L. A. (1965). The Genius of American Education. New York: Vintage Books.

Debord, G. (2002). The Society of the Spectacle. New York: Zone Books.

Dewey, J. (1944). Democracy and Education: An Introduction to the Philosophy of Education. New York: The Free Press.

Dewey, J. (1990). The School and Society: The Child and the Curriculum. Chicago, IL: University of Chicago Press.

Ellsworth, E. (1989). Why Doesn't This Feel Empowering? Working through the Repressive Myths of Critical Pedagogy. Harvard Educational Review, 59, 297-324.

Fiore, K., \& Elsasser, N. (1987). "Strangers No More”: A Liberatory Literacy Curriculum. In I. Shor (Ed.), Freire for the Classroom: A Sourcebook for Liberatory Teaching (pp. 87-103). Portsmouth, NH: Boynton/Cook.

Freeman, Y., \& Freeman, D. (1992). Whole Language for Second Language Learners. Portsmouth, NH: Heinemann.

Freire, P. (1998a). Teachers as Cultural Workers: Letters to Those Who Dare Teach. Boulder, CO: Westview.

Freire, P. (1998b). Pedagogy of Freedom: Ethics, Democracy, and Civic Courage. Lanham, MD: Rowman and Littlefield.

Freire, P. (2002). Pedagogy of the Oppressed. New York: Continuum.

Freire, P., \& Macedo, D. (1987). Literacy: Reading the Word and the World. South Hadley, MA: Bergin \& Garvey.

Giroux, H. (2001). Theory and Resistance in Education: Towards a Pedagogy for the Opposition (revised and expanded). Westport, CT: Bergin \& Garvey.

Giroux, H., \& McLaren, P. (1986). Teacher Education and the Politics of Engagement: The Case for Democratic Schooling. Harvard Educational Review, 56, 213-238.

Goering, S., Shudak, N. J., \& Wartenberg, T. E. (2013). Philosophy in Schools: An Introduction for Philosophers and Teachers. New York: Routledge.

Gur-Ze’ev, I. (1998). Towards a Nonrepressive Critical Pedagogy. Educational Theory, 48, 463-486. http://dx.doi.org/10.1111/j.1741-5446.1998.00463.x

Kincheloe, J. (2005). Critical Pedagogy Primer. New York: Peter Lang.

Knight, T., \& Pearl, A. (2000). Democratic Education and Critical Pedagogy. The Urban Review, 32, 197-226. http://dx.doi.org/10.1023/A:1005177227794

Larson, J. (2014). Radical Equality in Education: Starting over in US Schooling. New York: Routledge.

Lather, P. (1998). Critical Pedagogy and Its Complicities: A Praxis of Stuck Places. Educational Theory, 48, 487-498. http://dx.doi.org/10.1111/j.1741-5446.1998.00487.x 
Lather, P. (2001). Ten Years Later, Yet Again: Critical Pedagogy and It Complicities. In K. Weiler (Ed.), Feminist Engagements: Reading, Resisting, and Revisioning Male Theorists in Education and Cultural Studies (pp. 183-196). New York: Routledge.

Lipman, M. (1991). Thinking in Education. New York: Cambridge.

Liston, D. P., \& Zeichner, K. M. (1987). Critical Pedagogy and Teacher Education. Journal of Education, 169, 117-137.

McLaren, P. (1998a). Revolutionary Pedagogy in Post-Revolutionary Times: Rethinking the Political Economy of Critical Education. Educational Theory, 48, 431-462. http://dx.doi.org/10.1111/j.1741-5446.1998.00431.x

McLaren, P. (1998b). Life in Schools: An Introduction to Critical Pedagogy in the Foundations of Education (3rd ed.). New York: Longman.

Shor, I. (1987). Freire for the Classroom: A Sourcebook for Liberatory Teaching. Portsmouth, NH: Boynton/Cook Publishers.

Shor, I., \& Freire, P. (1987). What Is the “Dialogical Method” of Teaching? Journal of Education, 169, 11-31.

Tyack, D. (1974). The One Best System: A History of American Urban Education. Cambridge, MA: Harvard University Press.

Tyack, D., \& Cuban, L. (1995). Tinkering toward Utopia: A Century of Public School Reform. Cambridge, MA: Harvard University Press.

Wallerstein, N. (1983). Language and Culture in Conflict: Problem-Posing in the ESL Classroom. Reading, MA: AddisonWesley.

Weiler, K. (1988). Women Teaching for Change: Gender, Class and Power. South Hadley, MA: Bergin \& Garvey.

Weston, A. (2011). A Practical Companion to Ethics. New York: Oxford University Press.

Wink, J. (2005). Critical Pedagogy: Notes from the Real World (3rd ed.). Boston, MA: Pearson.

Yolen, J. (1996). Encounter. New York: Voyager Books. 
Scientific Research Publishing (SCIRP) is one of the largest Open Access journal publishers. It is currently publishing more than 200 open access, online, peer-reviewed journals covering a wide range of academic disciplines. SCIRP serves the worldwide academic communities and contributes to the progress and application of science with its publication.

Other selected journals from SCIRP are listed as below. Submit your manuscript to us via either submit@scirp.org or Online Submission Portal.
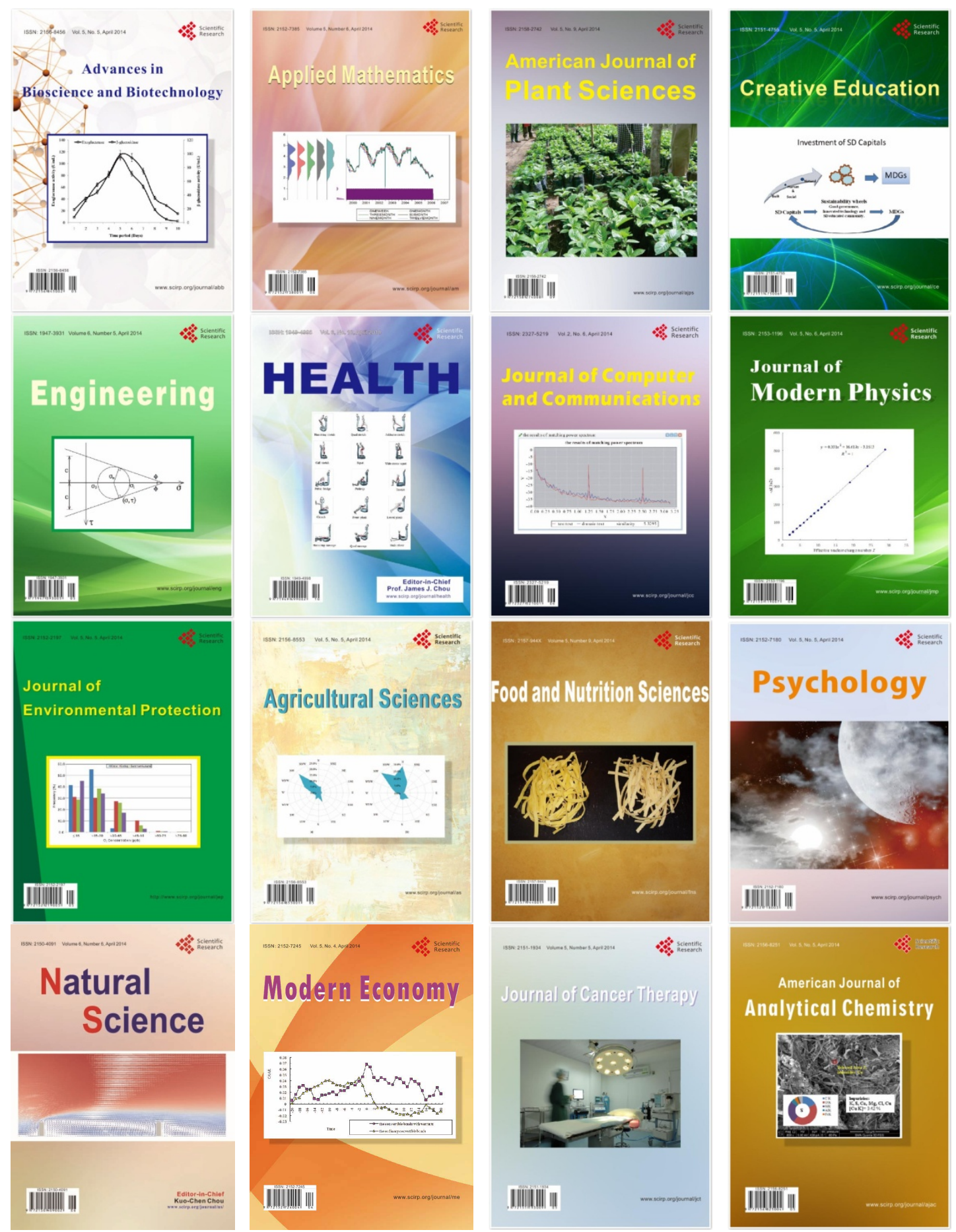